\title{
Description and biogeographic implications of a new species of the Chenistonia maculata group from south-western Western Australia and rediagnosis of Chenistonia (Araneae: Mygalomorphae: Nemesiidae)
}

\author{
Barbara York Main \\ School of Animal Biology M092, University of Western Australia, 35 Stirling Highway, Crawley, \\ Western Australia 6009, Australia. Email: Barbara.Main@uwa.edu.au
}

\begin{abstract}
The new species Chenistonia boranup is described from south-western Western Australia. This is the first record of the C. maculata species group from the western part of the continent. Chenistonia Hogg is rediagnosed and comments given on other species attributed here to the genus.
\end{abstract}

KEYWORDS: taxonomy, morphology, karri forest, Gondwanan relics

\section{INTRODUCTION}

The nemesiid spider genus Chenistonia Hogg, 1901 was synonymised with Aname Koch, 1873 by Raven (1981) but regarded as a valid genus by Main (1982a, 1985a,b, 1986, 1994) and elsewhere in ecological papers (Curry et al., 1985; Main, 1982b, 1987a,b, 1991, 1993a,b, 1996a,b, 1997; Main et al., 2000). Raven (1984, 1985) continued to consider Chenistonia as synonymous with Aname until acknowledging it later as a valid genus for which he gave a revised diagnosis (Raven, 2000). In the meantime, he recognised a group of species, some of which he newly described (Raven 1984), as having affinity with Aname maculata (Hogg, 1901) (the type species of Chenistonia) as the maculata group within Aname. In reinstating Chenistonia, Raven (2000) included only those species formerly attributed to the maculata group (e.g., A. caeruleomontana Raven, 1984, A. hickmani Raven, 1984, Chenistonia maculata, A. montana Raven, 1984 and Chenistonia trevallynia Hickman, 1926) in the genus, and retained other species previously attributed to Chenistonia in Aname. Raven (2000) retained A. tropica in Aname but made no mention of $A$. earthwatchorum although he had previously (Raven 1984) figured maxillae with a broad distribution of cuspules suggesting an affinity with Aname rather than Chenistonia.

Chenistonia is herein rediagnosed and distinguished from Aname, some of those species formerly included in Aname by Raven (2000) but which fit the new definition of Chenistonia are formally transferred accordingly and a new species of the maculata group from south-western
Australia is described and its biogeographic status indicated. For comparison, figures of the male of the type species are presented. The taxonomic position of Chenistonia trevallynia is also discussed.

\section{MATERIAL AND METHODS}

The material examined for this study is stored in $75 \%$ ethanol and lodged in the Museum of Natural History, London (BMNH) and the Western Australian Museum, Perth (WAM). A ZEISS citoval stereomicroscope was used during the study of the new species, and all measurements are in millimetres. The tibial index $=$ $100 \mathrm{x}$ dorsal proximal width of patella/length of tibia + patella (Petrunkevitch 1942).

The following abbreviations are used for the spination of the legs: v, ventral; d, dorsal; pv, prolatero-ventral; pd, prolatero-dorsal; rv, retrolatero-ventral; rd, retrolaterodorsal.

\section{SYSTEMATICS}

\section{Family Nemesiidae Simon, 1889}

\section{Chenistonia Hogg, 1901}

Chenistonia Hogg, 1901: 261; Main, 1985a: 31; Raven, 2000: 572 (other catalogue citations not listed here).

Proshermacha Simon, 1908: 363; Main, 1982a: 84 (first synonymised with Chenistonia). 


\section{TYPE SPECIES}

Chenistonia: Chenistonia maculata Hogg, 1901, by original designation.

Proshermacha: Proshermacha subarmata Simon 1908, by subsequent designation (Rainbow 1912).

\section{DIAGNOSIS}

Chenistonia differs from Aname primarily in the distribution of the maxillary cuspules which are generally in a narrow band less than a third the length of the ventral surface of the maxilla; an exception may be Chenistonia earthwatchorum (see Raven 1984 figures 23 and 26); and in the male by the elongate, ventrally depressed palpal tarsus (Figures 6,10), the pear shaped bulb (Figures 6, 10) and usually the absence of a retroventral bare area on the palpal tibia (Figure 6,10).

\section{DESCRIPTION}

Small to large, dark brown to black spiders, males sometimes with fuscous hairs on carapace. Carapace with low caput and not markedly rounded margins; fovea straight (Figure 1). Sternum cordate, posterior sigilla marginal, usually small and round or oval (Figures 3, 11). Cuspules on maxillae forming a narrow band (Figure 3), covering less than a third length of ventral surface of maxilla. Maxillary serrula present or absent. Leg tarsi without spines, palp tarsus of females and immature spiders usually with a basal pair of spines. Tarsus of male palp elongate, ventrally depressed and with bulb attached distally (Figures 5, 6, 710 ); when at rest the bulb fits into this depression. Bulb elongate, usually pear shaped (attached by broad end) and with embolus arising terminally (Figures 5, 6, $7,9,10$ ). Embolus short or long (in which case aligned with axis of bulb and not reflexed). Palpal tibia of male without a bare or depressed retro-ventral area but in those species which have a long embolus there may be a narrow, longitudinal bare line dividing the hairs or bristles and which accommodates the embolus when not extended. Tibia I in male with a spur bearing a heavy spine, often with an additional spine at base of spur (as in Figure 12).

\section{REMARKS}

Raven (2000) recognised Chenistonia as distinct from Aname with which he had previously regarded it as synonymous (Raven, 1981, p. 328; Raven 1985, p.87), although Main (1964, 1985 and elsewhere) had considered it as a valid genus. Raven's principal defining characters of Chenistonia were: in the male the elongate, ventrally excavate slender palpal tarsus; a distally attached pear shaped bulb with a short embolus (and thus not reflexed); and the first metatarsus with only a small (if present) basal process opposite the tibial spur. Further he noted in both sexes the small marginal sternal sigilla.

The genus is here rediagnosed taking into account several characters not mentioned by Raven (2000) in his diagnosis: most notably that it is into the ventral depression on the male palpal tarsus that the bulb fits when resting; the absence of a bare, often depressed, ventral patch on the male palp tibia (characteristic of most Aname species and into which the bulb fits when resting); and a narrow band of cuspules on the maxilla. I also recognise that many species of Chenistonia, albeit as yet undescribed, but which agree with the features noted above have a long embolus. Associated with this feature there is often an elongate, narrow bare strip on the retro/ventral aspect of the palpal tibia (where the embolus aligns when at rest).

The genus shares with the Teylini sensu Main, (1985b, 2004), the narrow band of maxillary cuspules but the Teylini genera have a relatively broader sternum and carapace, the latter with rounded sides, features not generally noted. The male of Chenistonia is distinguished by the pear shaped bulb with the embolus arising terminally (not equatorially as is usual in Teyl) and further (except for Teyloides) in the presence of a tibial spur on the first leg of the male.

\section{Additional taxonomic comments}

A maculata group of species is here recognised in which males have a short embolus as in the type species of the genus (see Figures 9, 10). This group thus includes those species included by Raven (2000) (according to his understanding of the genus) in Chenistonia except for C. trevallynia the generic position of which Raven questioned. The status of $C$. trevallynia will be discussed elsewhere (Main, unpublished data) along with that of certain other species transferred from Chenistonia to Aname by Raven (2000). Descriptions of several additional new species from south-western Western Australia will likewise be given elsewhere (Main, unpublished data).

\section{SPECIES HERE ATTRIBUTED TO CHENISTONIA}

\section{Species with short embolus}

Chenistonia maculata Hogg, 1901, from Victoria

Chenistonia caeruleomontana (Raven, 1984), from New South Wales

Chenistonia hickmani (Raven, 1984), from New South Wales

Chenistonia montana (Raven, 1984), from New South Wales

?Chenistonia earthwatchorum (Raven, 1984), from Northern Queensland

Chenistonia boranup sp. nov., from Western Australia.

Chenistonia trevallynia was retained by Raven (2000) in Chenistonia, but Raven (2000) also noted the anomalous short male palpal tarsus. The species is probably misplaced here. An undescribed 'sister' species occurs in south-western Western Australia, based upon a specimen in WAM (Main, unpublished data). 

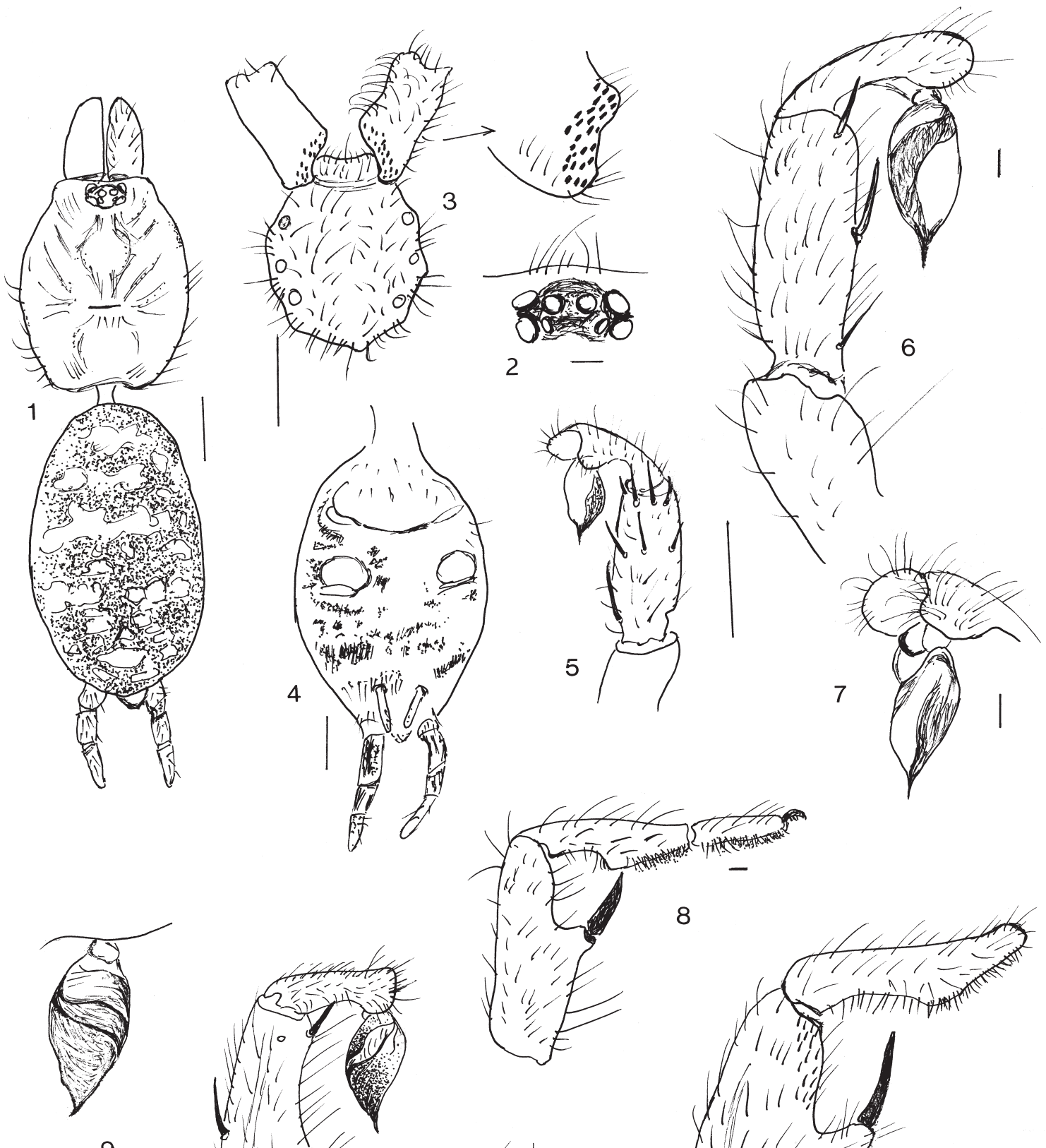

9
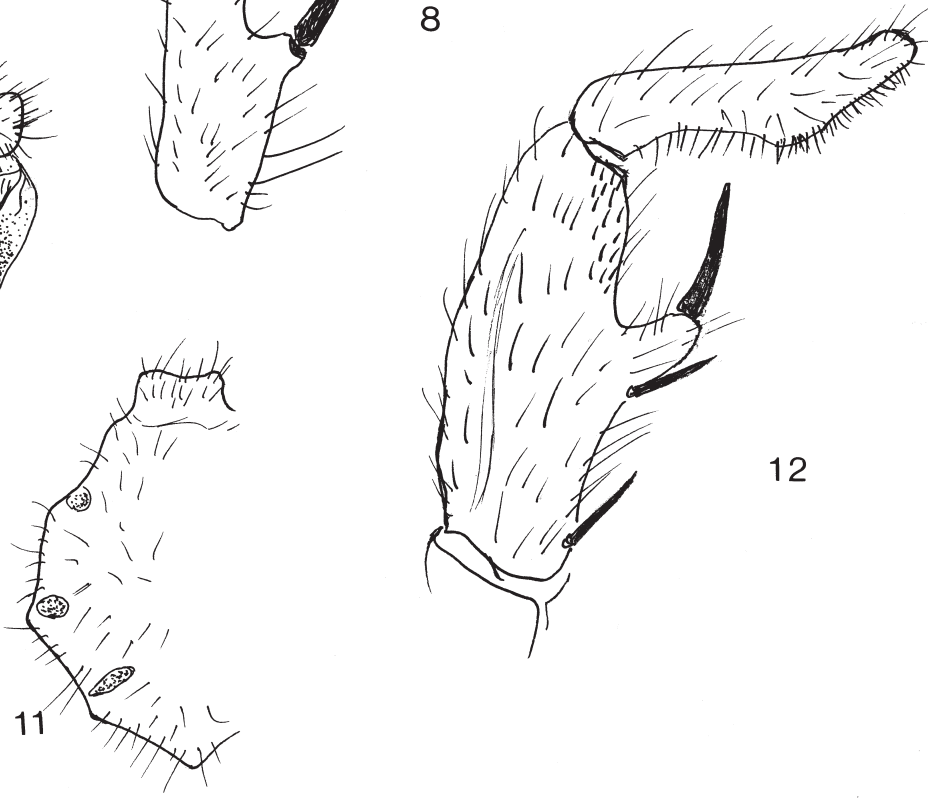

FIGURES 1-12 1-8, Chenistonia boranup sp. nov., holotype male (WAM 92/97): 1, carapace and abdomen, dorsal; 2, eyes; 3, labium, sternum, maxillae and enlarged coxal area; 4, abdomen, ventral; 5, 6, 7 right pedipalp, 5, prolateral view, tarsus and bulb and tibia; 6, retrolateral view tarsus and bulb and tibia; 7 , prolateral view tarsus tip and bulb; 8, right leg 1, retrolateral view. 9-12, Chenistonia maculata Hogg, syntype male $(\mathrm{BMNH})$ : 9, bulb of right pedipalp, prolateral; 10 , right pedipalp, retrolateral; 11 , sternum and labium; 12, right leg 1, retrolateral view of tibia and metatarsus. Scale for Figures $1-8=1.0 \mathrm{~mm}$ (approximate), and Figures 9-12 not to scale. 


\section{Species with long embolus}

Chenistonia cuspidata Main, 1954, from the Recherche Archipelago, Western Australia. Males of this species are known from south coastal mainland east of Esperance, but have not yet been formally described. There are also several other undescribed species in south-west Western Australia (Main, unpublished data). Although many males with a long embolus have been attributed to C. tepperi Hogg, 1902, by Main (1964 and elsewhere), this is possibly an error and the status of $C$. tepperi is currently under review (Main, unpublished data).

\section{Chenistonia boranup sp. nov.}

urn:Isid:zoobank.org:act:6432F0B9-9C58-49AD-9C3518D3683006F9

Figures 1-8, 13-19

\section{MATERIAL EXAMINED}

\section{Holotype}

Australia: Western Australia: $\widehat{\jmath}$, Boranup National Park, in karri (Eucalyptus diversicolor F. Mueller) forest, 21 August 1990, P.R. Davis and M. Widmar (WAM 92/97).

\section{DIAGNOSIS}

The male differs from those of other species of the Chenistonia maculata group as follows: from C. hickmani by the absence of tarsal spines; from C. caeruleomontana by the needle-pointed embolus (flattened in caeruleomontana) (see Raven 1984, key and figure 37); and from all other species named by Raven (1984) by the absence of spines on tibia I of males apart from the median spur (Figure 8); from C. maculata by the slightly elongate, straight and needlelike embolus whereas in $C$. maculata the embolus tip is slightly curved, and tibia I in C. maculata has a group of very short fine bristles retrolaterally between the spur and the distal end [see Figure 12 and faintly indicated in Raven (1981, Figure 11)], and the sternal posterior sigilla are more pronouncedly ovoid in $C$. maculata; also $C$. maculata is larger, with a carapace length of $5.5 \mathrm{~mm}$ (male syntype).

\section{DESCRIPTION}

Colour: generally dark brown, abdomen dorsally with pale mottled pattern on dark brown background, ventrally pale with few dark brown blotches.

Carapace: length/width $3.6 / 2.9 \mathrm{~mm}$, caput width 1.5 . Fovea short, straight. Eye group length/width 0.4/0.8. Carapace lateral margins with few long, posterior bristles and lateral group of bristles in mid-region, sparse hairs on posterior region. Maxillary cuspules in a narrow band.

Sternum: length/width 1.8/1.7, sigilla spherical, labium 0.3 long.

Chelicerae: without rastellum; ventral groove (right side) promargin with 7 retrolateral teeth, at least 10 small granules between proximal second and third teeth; left side with 8 retrolateral teeth and 15 small granules.

Abdomen: dorsally with sparse fine bristles. Spinnerets: posterior median pair $0.5 \mathrm{~mm}$ long; posterior lateral pair with basal segment 0.8 long, median 0.5 , terminal segment $0.8 \mathrm{~mm}$.

Legs: moderately hirsute. Spination: all tarsi without spines. Leg I (Figure 8), femur pd 1 apical, d 4 in median line. Leg II, metatarsus v 2-2-2, pd 1 median, tibia $\mathrm{v}$ $1-1-2$, pv 1 apical, pd 2, patella pd 1 apical, femur pd 1 apical, d median line $2+2$ bristles. Leg III, metatarsus v 2-2-2, rv 1 apical, d 2-2-2, tibia v 2-2-2, pv 1 apical, rv 1 apical, d 1-1, pd 2, rd 2, patella pd 2, rd 2, femur d 3 (median), pd 3, rd 2. Leg IV, metatarsus v 2-1-2-2, d 2-1-2, pd 3, rv 1 apical, rd 2, tibia v 2-2-2, d 1-1(median), pd 3, rd 2, p 3, pv 1 (apical), rv 1 apical. patella rd 1 ( +2 rd bristles). Scopula complete on tarsi I and II (but divided by line of bristles), sparse and only prolateroventral on III and IV; on metatarsi, only on distal half of I and II. Tarsal claws: uniform double combs of about 10 teeth on paired claws; median claw of legs III and IV long, without teeth. Trichobothria: not abundant on tarsi. Sensory ventral hairs with right angled alignment on metatarsi II, III and IV and tibiae I-IV.

Tibia I with large spur in mid-ventral region; upper angle of spur $0.9 \mathrm{~mm}$ from distal end of tibia, $1.2 \mathrm{~mm}$ from proximal end of tibia to base of spine, spine $0.8 \mathrm{~mm}$ long, upper base of spine $0.1 \mathrm{~mm}$ from upper junction of spur (Figure 8) Metatarsus I ventrally incrassate opposite tibial spur (Figure 8).

Palp: tarsus (Figures 5, 6, 7) with deep ventral excavation which accommodates the bulb when not extended; tarsus without spines. Bulb pear shaped (0.75 $\mathrm{mm}$ long) with small, pointed process (embolus) $0.15 \mathrm{~mm}$ in same axis as the elongate bulb; basal segment $0.1 \mathrm{~mm}$. Tibia spination (see Figures 5, 6) v 1-2-2, pd 1-1, rv 1 apical.

Measurements: palp: femur 2.0, patella 1.2, tibia 1.4, tarsus 1.0, total 5.6. Leg I, femur 2.7, patella1.3, tibia 2.1, metatarsus 2.0, tarsus 1.3, total 9.4. Leg II, femur 2.4, patella 1.5 , tibia 1.6 , metatarsus 1.7 , tarsus 1.2 , total 8.4 . Leg III, femur 2.2, patella 1.4, tibia 1.3, metatarsus 1.6, tarsus 1.2, total 7.7. Leg IV, femur 2.8, patella 1.6, tibia 2.2, metatarsus 3.0, tarsus 1.4 , total 11.0. Width patella IV at knee, 0.5 , tibial index $=13.1$.

\section{NATURAL HISTORY}

Collectors of the type specimen of $C$. boranup noted that it was collected in karri (Eucalyptus diversicolor F. Mueller) forest. While I acknowledge here that many of the small female and immature specimens collected in the karri forest, particularly specimens from silk tubes in logs and litter are possibly of this new species, until similar specimens are collected contiguously or at least in propinquity with males it is currently expedient not to attribute such specimens to the new species. Raven (1984) noted that the maculata group of species have been found only 'in perennially cool buffered forests'. 


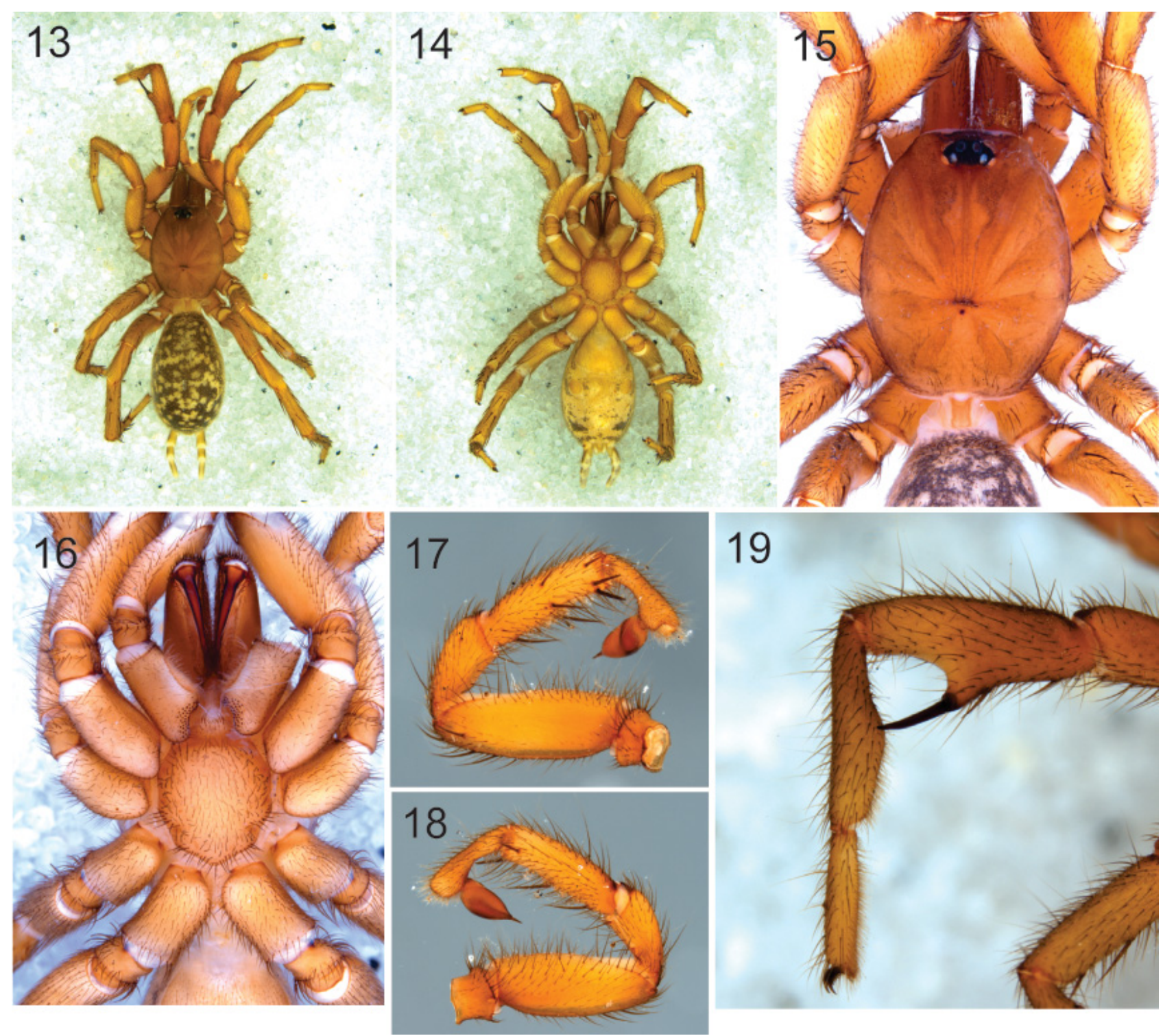

FIGURES 13-18 Chenistonia boranup sp. nov., holotype male (WAM 92/97): 13, dorsal view; 14, ventral view; 15, dorsal view of carapace; 16, ventral view of sternal area, note maxillae and cuspules; 17, left palp prolateral; 18 , left palp retrolateral; 19, left leg I retrolateral tibia, metatarsus and tarsus.

\section{Distribution}

All previously named species have come from Victoria (C. maculata), and New South Wales and Queensland. The new species C. boranup is here regarded as relictual from a former southern Gondwanan distribution presumably fragmented due to periods of dryer climate and reduced forest habitat.

\section{ACKNOWLEDGMENTS}

I am grateful for access to collections in the Western Australian Museum afforded by Dr Mark Harvey and Julianne Waldock where the above specimen was located while I was sorting Aname specimens. I am indebted to Mark Harvey for taking the photographs of the new species. I also acknowledge the curators of the Arachnology collections in the British Museum of
Natural History (now The Natural History Museum), London for access to the collections on my various visits, firstly in 1958 when I examined and prepared figures of the male syntype specimen of the generic type species Chenistonia maculata.

\section{REFERENCES}

Curry, S.J., Humphreys, W.F., Koch, L.E. and Main, B.Y. (1985). Changes in arachnid communities resulting from forestry practices in karri forest, south-west Western Australia. Australian Forestry Research 15: 469-480.

Hogg, H.R. (1901). On Australian and New Zealand spiders of the suborder Mygalomorphae. Proceedings of the Zoological Society of London 1901(2): 218-279.

Hogg, H.R. (1902). On some additions to the Australian spiders of the suborder Mygalomorphae. Proceedings of the Zoological Society of London 1902(2): 121-142. 
Koch, L. (1873). Die Arachniden Australiens, volume 1, pp. 369-472. Bauer und Raspe: Nürenburg.

Main, B.Y. (1964). Spiders of Australia. Jacaranda Press: Brisbane, Queensland.

Main, B.Y. (1982a). Further studies on the systematics of Australian Diplurinae (Araneae: Mygalomorphae: Dipluridae): the taxonomic status of Proshermacha Simon and Chenistonia tepperi Hogg. Australian Entomological Magazine 8: 83-88.

Main, B.Y. (1982b). Adaptations to arid habitats by mygalomorph spiders. In: Barker, W.R. and Greenslade, P.J.M. (eds), Evolution of the Flora and Fauna of Arid Australia: 273-283. Peacock Publications: Frewville, South Australia.

Main, B.Y. (1985a). Mygalomorphae. In: Walton, D.W. (ed.), Zoological Catalogue of Australia, vol. 3, pp. 1-48. Bureau of Flora and Fauna, Australian Government Publishing Service: Canberra.

Main, B.Y. (1985b). Further studies on Australian Diplurinae: A review of the genera of the Teylini (Araneae: Mygalomorphae: Diplurinae). Australian Journal of Zoology 33: 743-759.

Main, B.Y. (1986). Further studies on the systematics of Australian Diplurinae (Araneae: Mygalomorphae: Dipluridae): a new genus from south-western Australia. Records of the Western Australian Museum 12: 395-402.

Main, B.Y. (1987a). Persistence of invertebrates in small areas: Case studies of trapdoor spiders in Western Australia. In: Saunders, D.A., Arnold, G.W., Burbidge, A.A. and Hopkins, A.J.M. (eds). Nature Conservation: The Role of Remnants of Native Vegetation, pp. 29-39. Surrey Beatty and Sons. Chipping Norton, N.S.W.

Main, B.Y. (1987b). Ecological disturbance and conservation of spiders: implications for biogeographic relics in southwestern Australia. In: Majer, J.D. (ed). The role of Invertebrates in Conservation and Biological Survey: pp. 89-97. Western Australian Department of Conservation and Land Management Report: Perth, W.A.

Main, B.Y. (1991). Trapdoor spiders. In: Werren, G. and Kershaw, P. (eds). The Rainforest Legacy: 363-364. Australian National Rainforests Study. Australian Government Publishing Service, Canberra.

Main, B.Y. (1993a). Spiders and other invertebrates. In: Thomson, C., Hall, G. and Friend, G. (eds). Mountains of Mystery: 117-124. Department of Conservation and Land Management: Perth, W.A.

Main, B.Y. (1993b). Spiders of the Stirling Range. Landscope
8(3): 28-34.

Main, B.Y. (1994). Biosystematics of Australian mygalomorph spiders: description of a new species of Aname and its aerial tube (Aranae: Nemesiidae). Journal of the Royal Society of Western Australia 77: 65-69.

Main, B.Y. (1996a). Microcosmic biogeography: trapdoor spiders in a time warp at Durokoppin. In: Hopper, S.D, Chappill, J.A., Harvey, M.S., and George, A.S. (eds), Gondwanan Heritage: Past, Present and Future of the Western Australian Biota: 163-171. Surrey Beatty and Sons: Chipping Norton, N.S.W.

Main, B.Y. (1996b). Terrestrial invertebrates in south-west Australian forests: the role of relict species and habitats in reserve design. Journal of the Royal Society of Western Australia 79: 277-280.

Main, B.Y. (1997). Tropical rainforest mygalomorph spiders in the Australian desert: the irony of an adaptive legacy. Memoirs of the Museum of Victoria 56: 339-347.

Main, B.Y. (2004). Biosystematics of Australian mygalomorph spiders: descriptions of three species of Teyl from Victoria (Araneae: Nemesiidae). Memoirs of the Museum of Victoria 61(1): 47-55.

Main, B.Y., Sampey, A. and West, P.L.J. (2000). Mygalomorph spiders of the southern Carnarvon Basin, Western Australia. Records of the Western Australian Museum, Supplement No. 61: 281-293.

Petrunkevitch, A. (1942). A study of amber spiders. Transactions of the Connecticut Academy of Arts and Sciences 34: 119-464.

Rainbow, W.J. (1912). A census of Australia Araneidae and index to families, subfamilies and genera. Records of the Australian Museum 9(2): 107-319.

Raven, R.J. (1981). A review of the Australian genera of the mygalomorph spider subfamily Diplurinae (Dipluridae: Chelicerata). Australian Journal of Zoology 29: 321-363.

Raven, R.J. (1984). A revision of the Aname maculata species group (Dipluridae, Araneae) with notes on biogeography. Journal of Arachnology 12: 177-193.

Raven, R.J. (1985). The spider infraorder Mygalomorphae (Araneae): Cladistics and systematics. Bulletin of the American Museum of Natural History 182: 1-180.

Raven, R.J. (2000). Taxonomica Araneae I: Barychelidae, Theraphosidae, Nemesiidae and Dipluridae (Araneae). Memoirs of the Queensland Museum 45: 569-575.

MANUSCRIPT RECEIVED 11 JULY 2012; ACCEPTED 17 OCTOBER 2012. 